\title{
Article \\ Deliberative Political Leaders: The Role of Policy Input in Political Leadership
}

\author{
Jennifer Lees-Marshment \\ School of Social Sciences, Politics and International Relations, The University of Auckland, Auckland 1010, New Zealand; \\ E-Mail: j.lees-marshment@auckland.ac.nz
}

Submitted: 14 January 2016 | Accepted: 9 March 2016 | Published: 23 June 2016

\begin{abstract}
This article provides a fresh perspective on political leadership by demonstrating that government ministers take a deliberative approach to decision making. Getting behind the closed doors of government through 51 elite interviews in the UK, US, Australia, Canada and New Zealand, the article demonstrates that modern political leadership is much more collaborative than we usually see from media and public critique. Politicians are commonly perceived to be powerhungry autocratic, elite figures who once they have won power seek to implement their vision. But as previous research has noted, not only is formal power circumscribed by the media, public opinion, and unpredictability of government, more collaborative approaches to leadership are needed given the rise of wicked problems and citizens increasingly demand more say in government decisions and policy making. This article shows that politicians are responding to their challenging environment by accepting they do not know everything and cannot do everything by themselves, and moving towards a leadership style that incorporates public input. It puts forward a new model of Deliberative Political Leadership, where politicians consider input from inside and outside government from a diverse range of sources, evaluate the relative quality of such input, and integrate it into their deliberations on the best way forward before making their final decision. This rare insight into politician's perspectives provides a refreshing view of governmental leadership in practice and new model for future research.
\end{abstract}

\section{Keywords}

consultation; decision making; deliberation; deliberative political leadership; government; ministers; political leadership; politicians; public input

Issue

This article is part of the issue "New Approaches to Political Leadership", edited by Mark Bennister (Canterbury Christ Church University, UK).

(C) 2016 by the author; licensee Cogitatio (Lisbon, Portugal). This article is licensed under a Creative Commons Attribution 4.0 International License (CC BY).

\section{Introduction}

Academic research argues that the formal power of our political leaders is circumscribed by the media and public opinion and more collaborative approaches to leadership are needed given the rise of wicked problems and citizen demands for more say in government decisions and policy making. Through 51 interviews with government ministers in the UK, US, Australia, Canada and New Zealand about their leadership, approach and use of public input in decision making this article demonstrates that politicians are responding to their challenging environment by accepting they do not know everything and cannot do everything by themselves. They are moving towards a leadership style that is more deliberative in nature because it considers and integrates input from a range of sources before making final judgements. The article provides and overview of previous literature, outlines the methodology used in new empirical research, and presents a new model of Deliberative Political Leadership drawn from this empirical data for use in future research. 


\section{Overview of Previous Research: The Need for New Forms of Political Leadership}

Politicians are conventionally viewed as power seeking individuals; seeking power through elections in order to use the formal authority and resources of government to implement their vision given that the official position of prime minister or minister generates formal and informal power (see Burkhardt \& Glass, 2010, p. 560; Komives \& Dugan, 2010, p. 111). However a review of previous research finds that many have argued that theoretically political leadership should include representing majority and minority views, creating a sense of vision, nudging the public to new directions, and utilising superior skills including media management, crisis management and practical governing to secure significant change (see Elgie, 1995, p. 3, or Lees-Marshment, 2015, Chapter 2 for detailed literature discussion).

Empirically research has also argued that leaders can no longer act as power-wielding superiors because there are a number of challenges that they face. Not only are there the constraints on power that those such as Neudstadt (1960) noted, in the $21^{\text {st }}$ century the public are harder to persuade to accept new ideas (Brooker, 2005, p. 22); less trusting of political leaders (Hartley \& Bennington, 2011, p. 205); and want their own views to be listened and responded to (Barber, 1988, p. 3; Coleman, 2005, p. 273). As Kane and Patapan (2012, p. 18) explain, whilst political leaders still make significant decisions they do so on behalf of all the people who can of course remove them from power at the next election and they thus have to 'carefully balance authority with submission, command with obedience, and power with deference'. A notable example of this is how President Obama sought election as president in 2008 to enact universal health care in the US, fought to get the legislation through Congress, continued to battle to prevent it being repealed by Republican opposition and manage government shutdown at the end of 2013, and then engaged in a communications campaign to get the public to sign up to ensure it was a success on the ground. Political leaders also have to manage wicked policy problems such as climate change, obesity, binge drinking and ageing of the population where there is no clear cut support for a particular direction (Hartley, 2011, p. 333; Hartley \& Bennington, 2011, p. 206). Add in the overall context of a political marketing environment (Lees-Marshment, 2012) and politicians are unable to simply do what they think is right. There is also a greater public desire for participation in government decisions. As Sorensen (2006, p. 98) argues, 'we are witnessing a change in the way society is being governed'; a move from a focus on formal institutions of governance to a more fluid behavioural interactive process of governance where 'an increasing number of public and private actors have a substantial effect' on how society is run.
As for how leaders should respond to these challenges, again we have plenty of conceptual strategies, models and approaches that political leaders might adopt to maintain support and achieve their goals. Terms discussed in the literature include broker, chameleonic, charismatic, consultative, entrepreneurial, managerial, mobilising, reactive, servant and visionary (e.g. Elgie, 1995, p. 4; Peele, 2011, pp. 234-235). Research also discusses the importance of particular skills including agenda setting, communicating, game playing, adapting and being self-aware (e.g. Bell, Hargrove, \& Theakston, 1999; Boin, McConnell, \& t'Hart, 2010, pp. 234-236; Genovese, 2008). There is significant research on how leaders have used communication and media management to attract public attention to gain support for their policy proposals (e.g. Edwards \& Wood, 1999; Helms, 2005; Kernell, 1986); other work argues politicians utilise public opinion to inform their decisions (e.g. Jacobs \& Shapiro, 2000); whereas others talk about leaders needing to interact with followers (Burns, 1977, p. 274). Broader literature including nonpolitical work suggests a number of new approaches to fit an environment of increased public input into politician's decisions such as learning (Burkhardt \& Glass, 2010, p. 567); reflective (Goodin, 2009); facilitative; (Cheyne, 2004; Genovese, 1994, p. 24; Lipman-Blumen, 2010, pp. 772-773; Sorensen, 2006, p. 104); interactive (Klijn \& Koppenjan, 2000) and appreciative (Whitney, 2007 , p. 338). As Masciulli and Knight (2009, p. 117) argue, 'leaders should be able to choose from a leadership repertoire (or toolbox)' and offer a 'mixed collaborative leadership style that works best to suit given circumstances'. And research in non-leadership fields such as public administration also talks about the need for more participatory forms of government using terms such as collaboration, active citizenship, cooperative inquiry and co-creation (see LeesMarshment, 2015, Chapter 2. Figure 2.8).

This overview of previous literature demonstrates that there are a range of ideas in the literature about new forms of leadership that politicians might adopt. However, there is a gap in empirical research on recent political leadership-i.e. not what political leaders should do, or need to do, but what they really do in practice. We say leaders should be evolving, we argue they need to be, but we have not yet explored whether and how they might be actually doing that. This research therefore sought to fill this gap by interviewing political leaders in order to get a sense of what political leadership is like in reality. The next section outlines the methodology before presenting the new empirical research.

\section{New Research Methodology: Interviews with Government Ministers}

This new research sought to get behind closed doors 
and asking politicians directly what they thought of and how they used public input in central or federal government where constraints and pressures are greatest. The research therefore conducted in-depth interviews with 51 government ministers who were, or had been, in power during the administrations of Prime Ministers David Cameron, Stephen Harper, Kevin Rudd/Julia Gillard, John Key and President Obama to obtain their perspective on how public input can be used in government and within a leadership framework.

Public input was defined broadly, including market research, policy research, meetings between members of the public and politicians both formal/organised and informal/spontaneous, public letters/emails/calls to politicians, formal consultation including legislative hearings, and deliberative events. Any form of input that conveyed the views, experiences, behaviour and knowledge of those in society who are not elected or unelected figures (i.e. politicians) in government was considered relevant. Ministers and secretaries were chosen because they meet the definition of being in a position of senior political leadership. They are typically elected politicians, who have significant decision making power and budgets and their actions are highly visible to the public through media coverage and are subject to public input and opinion (see Hartley, 2012, p. 101). In the US this included secretaries who are the most appropriate equivalent; and in the UK it also included Baronesses and Lords in significant positions (see Riddell, Gruhn, \& Carolan, 2011, p. 33, who also include Lords).

The challenges of securing interviews with political elites has been well documented. As Richards (1996, p. 200) noted, 'by definition, elites are less accessible' and 'inevitably, elite interview samples tend to be a lot smaller'. Rhodes, t'Hart and Noortdegraaf (2007, p. 214) discuss how 'ministers and permanent secretaries are powerful men and women. They can refuse interviews, deny access to the organisation, declare documents secret, and insist on anonymity for both themselves and their organisation'. In their work on politician's views on deliberation Nabatchi and Farrar (2011, p. 3) secured just 11 interviews with state legislators, and failed to secure interviews with federal politicians. Whilst this research could have aimed lower, such as councillors in local government, to get at the leadership dimension it was important to analyse leaders working at top levels of government with all the related pressures decision making at that level includes. A plan for getting access and conducting the interviews was drawn up utilising literature on interviewing political elites, such as Aberbach and Rockman (2002), Goldstein (2002), Lilleker (2003) and Richards (1996); and advice on the letters to be sent was sought from former political advisors to prime ministers. Knowing from previous research that there was a strong potential for a poor response rate led to firstly a letter being sent by post and then at least a further 3 contact attempts made where email was available. Not surprisingly, the US was under represented in the sample, arguably due to the lack of public contact details for secretaries contact details (ministers, in contrast, are also elected MPs who need to be publicly contactable). But overall, securing 51 interviews with senior level politicians in central or federal government was a significant achievement. In the total list there were 272 potential interviewees for all 5 countries, so 51 represents a $19 \%$ response rate, with the interviews producing over 150,000 words in total. See Figure 1 for a list of those interviewed.

1. Alan Griffin, former Australian Minister for Veteran Affairs

2. Andrew Mitchell, former UK Secretary of State for International Development

3. Baroness Neville-Jones (Pauline), former UK Minister of State for Security \& Counter-Terrorism

4. Brendan O'Connor, former Australian Minister for Immigration and citizenship; Employment Participation; Home Affairs; Homelessness/Housing; Small Business; Humane Services; Justice; and Privacy

5. Caroline Spelman, former UK Secretary of State for the Environment, Food and Rural Affairs

6. Cheryl Gillan, former UK Secretary of State for Wales

7. Chris Evans, Former Australian Minister for Immigration and Citizenship; and Tertiary Education, Skills, Science and Research

8. Chuck Strahl, former Canadian Minister of Agriculture and Agri-Food, Minister of Indian Affairs and Northern Development, Minister of Transport, Infrastructure and Communities and Minister for the Canadian Wheat Board.

9. Craig Emerson, former Australia Minister for Competition Policy \& Consumer Affairs; Small Business, Independent Contractors \& the Service Economy; and Trade \& Competitiveness

10. David Emerson, former Canadian Minister of International Trade; Minister of Foreign Affairs; and Minister for the Pacific Gateway and the Vancouver-Whistler Olympics

11. David Ogden, former US Deputy Attorney General

12. Gary Grindler former US acting Deputy Attorney General

13. Jason Clare, former Australian Minister for Home Affairs and Justice, and Defence Material

14. Jean-Pierre Blackburn, former Canadian Minister of Veteran's Affairs; National Revenue; and Minister of State for Federal Economic Development; and Agriculture

15. John Banks, New Zealand Minister for Regulatory Reform and Small Busines

16. John Boscawen, former New Zealand Minister of Consumer Affairs

17. Lindsay Tanner, Former Australian Minister for Finance and Deregulation

18. Lord Howell (David) Former UK Minister of State (Foreign and Commonwealth Office) 
19. Lord Green (Stephen), UK Minister of State For Trade and Investment

20. Lord McNally (Tom) UK Minister of State (Justice)

21. Minister Bill English, Deputy Prime Minister of New Zealand and New Zealand Minister of Finance

22. Minister Candice Bergen, Canadian Minister of State for Social Development

23. Minister Chester Borrows, New Zealand Minister for Courts

24. Minister Craig Foss, New Zealand Minister of Commerce, Minister of Broadcasting and Minister of Consumer Affairs and former Minister for Civil Defence, Racing and Senior citizens

25. Minister Jonathan Coleman, New Zealand Minister of Defence and Minister of State Services and former Immigration Minister and Broadcasting Minister

26. Minister Judith Collins, New Zealand Minister of Justice, Minister for ACC, Minister for Ethnic Affairs and former Minister for the Police, Corrections and Veterans Affairs

27. Minister Michael Woodhouse, New Zealand Minister for Veterans Affairs and Immigration

28. Minister Murray McCully, New Zealand Minister for Foreign Affairs

29. Minister Nikki Kaye, New Zealand Minister for Food Safety, Minister of Civil Defence and Minister of Youth Affairs

30. Minister Oliver Letwin, UK Minister for Policy

31. Minister Paula Bennett, New Zealand Minister for Social Development and Youth Affairs/Employment

32. Minister Pita Sharples, New Zealand Minister for Maori Affairs

33. Minister Simon Bridges, New Zealand Energy and Resources and Minister of Labour and former Minister of Consumer Affairs

34. Minister Steven Joyce, New Zealand Minister for Tertiary Education, Skills and Employment

35. Minister Tony Burke, Australian Minister for Sustainability, Environment, Water, Population and Communities

36. Minister Tony Clement, Canadian Minister for the Federal Economic Development Initiative for Northern Ontario and former Minister of Health and Minister of Industry

37. Monte Solberg, former Canadian Minister for Citizenship \& Immigration; and for Human Resources and Skills Development

38. Peter Kent, former Canadian Minister of State for Foreign Affairs and Minister of the Environment

39. Ray La Hood, former US Secretary of Transport

40. Rob Merrifield, former Canadian Minister for Transport

41. Robert Debus, Former Australian Minister for Home Affairs

42. Robert McClelland, former Australian Attorney-General; Minister for Emergency Management; Homelessness; and Housing

43. Rodney Hide, former New Zealand Minister for Local Government and Regulatory Reform

44. Secretary Vincent Cable, UK Secretary of State for Business Innovation and Skills

45. Senator Kim Carr, former Australian Minister of Innovation, Science and Research; and Human Services

46. Sharon Bird, former Australian Minister for Higher Education and Skills

47. Simon Crean, former Australian Minister for Regional Australia, Regional Development and Local Government

48. Sir Gerald Howarth, former UK Minister for International Security Strategy

49. Sir Nick Harvey, former UK Minister of State for the Armed Forces

50. Steven Fletcher, former Canadian Minister for Democratic Reform and Transport

51. Stockwell Day, former Canadian Minister for International Trade, Emergency Preparedness and Asia-Pacific

Figure 1. Ministers and secretaries interviewed from the Rudd/Gillard, Harper, Key, Cameron and Obama governments 2013-2014.

As Peele (2005) advocates, studies of political leadership need to be open to 'experimentation with different approaches, techniques and frameworks' in order to 'unlock the secrets of what is a multifaceted process'. To increase the chances of finding new perspectives, and avoid the trap of falling into standard critique of politicians, the interviews adopted an appreciative inquiry approach. There is already a vast literature identifying weaknesses in the practice of collecting and using public input which tends to a common view that politicians are to blame for many of the problems. An appreciative inquiry approach seeks to identify what might actually work - the best of existing behaviour and potential for future development (Cooperrider, Whitney, \& Stavros, 2008). As Lilleker (2003, p. 208) noted, the benefits of elite interviews include 'insights into events about which we know little: the activities that take place out of the public or media gaze'. Such interviews provided an insight into what goes on in the minds of key decision makers. Cooper- rider et al.'s (2008) suggestions for appreciative inquiry approach questions were considered and adapted to produce new questions in the same style, which were more reflective and constructive. This helped to create a more comfortable place for politicians and may have increased the response rate. The ethical framework may also have helped, as it provided the ministers with the chance to edit transcripts before they were used in the research, even if only 4 made significant changes; (the rest made none or corrections to grammar/ names/facts only).

The 5 countries gave a reasonable spread in terms of ideology, with two left-leaning governments; two right-leaning governments and one right/liberal coalition. More former than current ministers were interviewed (61 versus 31\%); and-not surprisingly-more men than women, but no discernible impact on the data was found. To facilitate reflection on any potential differences in interview data by country, quotes were colour coded by country, and whilst very minor differ- 
ences were noted such as a greater tendency to critique civil servants in Australia and less favouring of consultative styles of leadership in Canada they were not large or solid enough to change the overall conclusions.

Whilst politicians' perspectives - like any subjectproduce highly subjective data (Richards, 1996, p. 201) because we have nothing of this nature in existing research, and that political leadership is about high level individuals rarely accessed by researchers, the data produced gives an invaluable insight not previously seen. As the aforementioned quote from Peele suggests, political leadership can be a somewhat secretive processes, and the value of interviews is it enables us to go behind usually closed doors, thus doing as Richards (1996, p. 200) argues and 'provid[ing] the political scientist with an insight into the mind-set of the actor/s who have played a role in shaping the society in which we live'.

Interviews were analysed and organised under the question headings, grouped into three main themes: managing public input, integrating public input into decision making, and new forms of political leadership with nearly 85,000 words of organised interview data before identifying of overall themes in political leadership behaviour. This data provided ground breaking insights into the changing roles of political leaders. From this, a new model of Deliberative Political Leadership was created which is presented below.

\section{Research Results: Emergence of Deliberative Political Leaders}

This section presents the results of the empirical re- search by presenting a new model of political leadership derived from the data, called Deliberative Political Leadership. Deliberative political leaders consider constructive and conversational input from inside and outside government from a diverse range of sources, evaluate the relative quality of such input, and integrate the input into their deliberations on what is the best way forward before making their final decision. There are four core components to this leadership model: see Figure 2.

This model of Deliberative Political Leadership connects and combines the concept of deliberation from the deliberative democracy field with leadership from political leadership field. It is fully acknowledged that the term deliberative is an area of major debate-as indeed is leadership-but this research is simply focusing on core principles from both concepts. So in deliberation, a range of inputs and perspective should be considered and issues should be discussed in a constructive manner; in leadership and leaders should listen, show vision, and make decisions.

Below the data that informed the creation of this model is presented. Firstly, discussion explores how ministers accept lack of power and knowledge, therefore proactively seek constructive public input and evaluate its quality. Secondly it demonstrates how they adopt the four components of the Deliberative Political Leadership Model: getting out and about, being consultative, sharing solution finding and judging. Thirdly it discusses why ministers thought that taking these approaches was valuable to them in their leadership role.

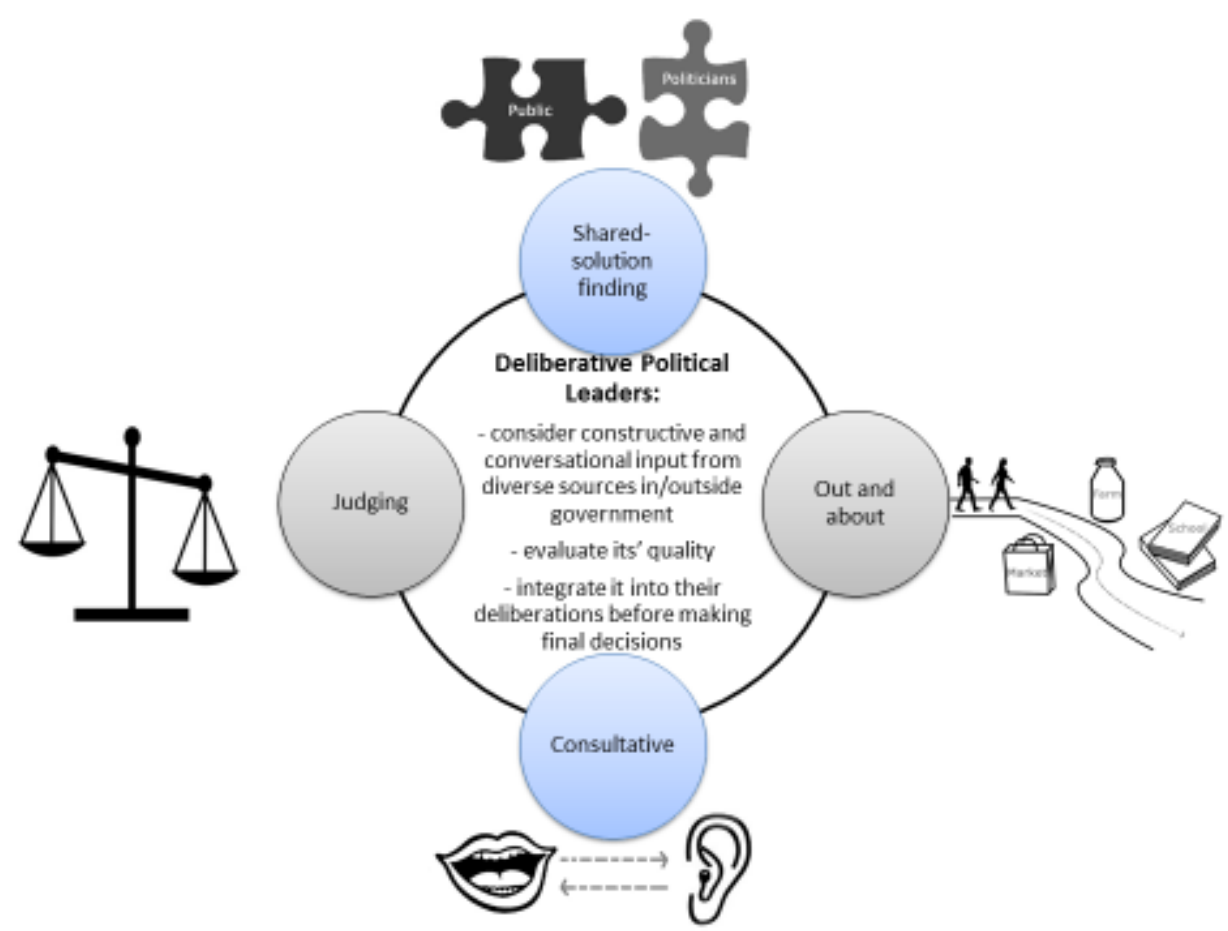

Figure 2. Model of deliberative political leadership. 


\subsection{Ministers' Accepted Lack of Power and Knowledge}

The same constraints on leadership noted in academic literature were acknowledged by the ministers when interviewed. The power bestowed to our leaders is now very limited; as one minister noted 'it's certainly not a, as you say, "get yourself into a leadership position and then tell people what to do thing" because the world's not like that' (Joyce). As the public is more connected and informed they want to be heard, making governing more complex. Ministers also conceded the limits of their knowledge and capacity and that they seek expertise from elsewhere. Figure 3 displays some of the comments made in interviews.

\subsection{Ministers Proactively Seek Constructive Public Input}

Secondly, and in response to this, ministers proactively seek diverse constructive public input and do so from a range of different sources: academic experts; think tanks; overseas research based/policy advice; professional associations; frontline staff; civil servants; organised stakeholders; individual stakeholders; general public; underrepresented; formal consultation/submissions; market research. Ministers expressed significant respect for the public perspective, with Bill English, NZ Deputy Prime Minister noting that 'the models of hairy-chested change all assume the public are pretty stupid and can't quite understand the issues and will be irrationally resistant to change, and that's generally wrong'. However they also discussed the value of government staff, outside experts, professionals and so on. No one source emerged as superior to the others.

Indeed, the overall conclusion was that when it comes to finding the best policy solution, no one is god. Not the minister, not an NGO, not a policy expert. One interviewee commented 'you shouldn't assume that there is some god-like creature that can have some tablets of stone that they can hand down to you as to what is actually occurring in society' (Carr). Ministers need to 'get a range of input' (Coleman); that they 'shouldn't rely on one source. No matter how good they are, 'everybody gets it wrong sometimes' (Griffin). Each method or source has 'their own benefits' (Bergen) so input has 'to come from a number of different sources in order to be valid' (Clement) and 'a number of different mechanisms' (Clare) should be used. Given this, it was important to actively seek alternative sources of information:

'As a minster you're not passive...You're not just an empty vessel. You're not just a receiver. A minster's job is to actually be engaged' (Carr).

'Good ministers go out and seek alternative points of view to challenge the advice that they've been given' (Clare).

'You've always got to be engaged in a bit of lateral thinking and thinking "ok, who else is effected by this? Who else should I need to be talking to?"... I made a conscious effort to engage with people that hadn't been engaged with before' (Gillan).

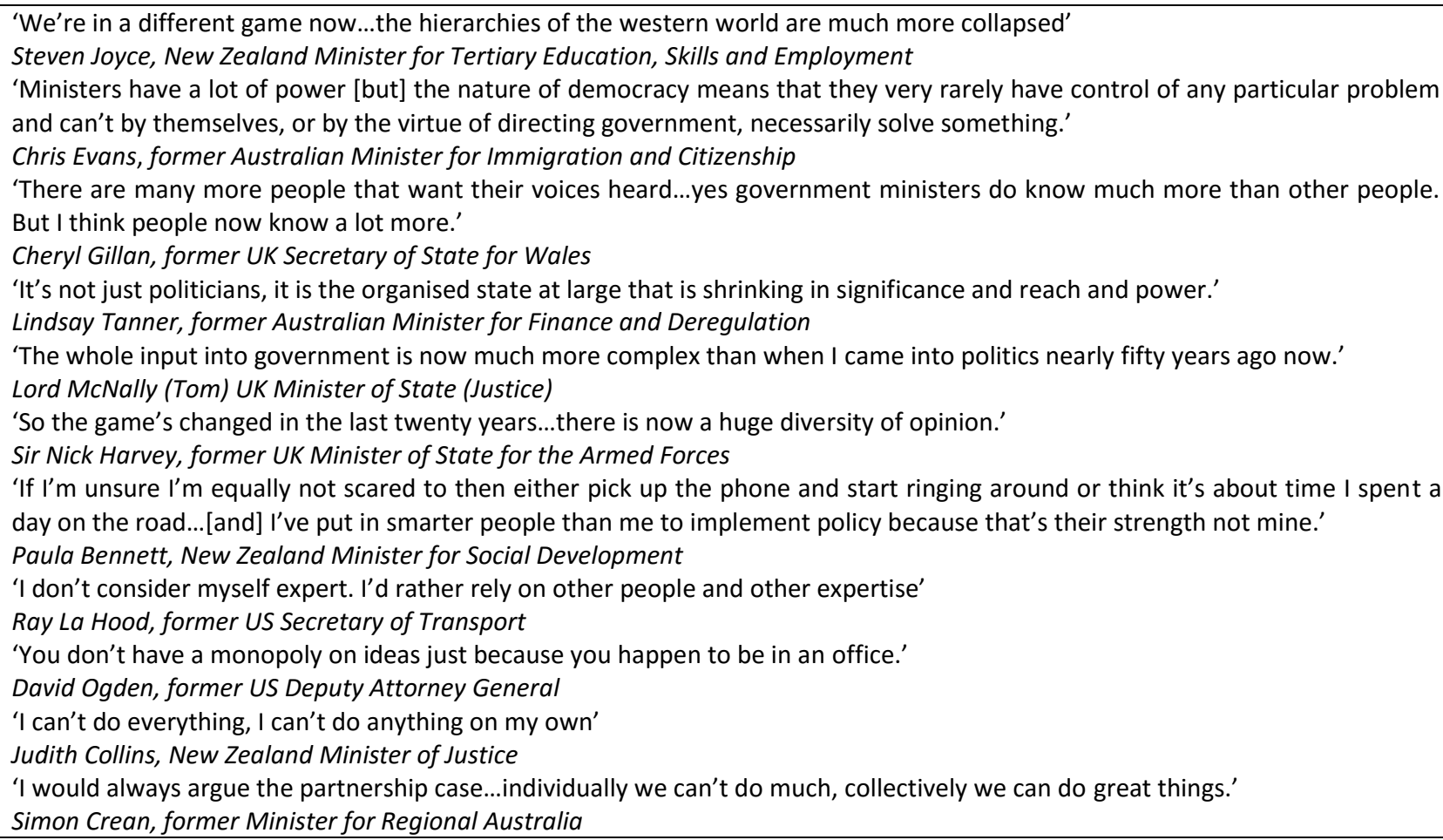

Figure 3. Ministers' reflections on their limited power and knowledge. 
'You've got to push to make sure you're exposed to the conversation, because everything around you will try to prevent it...when I was Agriculture Minister I said “ok, well I come from the city, I don't come from a farming background, I'm going to go off and spend a lot of time on farms"... when I came back [departmental staff said] "ok, well now you've done all the travelling, we can now get some real work done"...it was viewed as sort of a stunt...and I was like "no no no, this is how I operate. This is what I'll do." So you need to keep pushing to make sure that you're having your meetings on the ground, because the bureaucracy, generally, will function through formalised meetings with peak bodies' (Burke).

\subsection{Ministers Evaluate the Quality of Input}

Thirdly, ministers also evaluate the quality of input they receive before taking it into account. For example, they reflect on whether public opinion is uninformed or influenced by misconception. As one interviewee commented 'that's why you have to have structured consultations and you have to have carefully designed surveys in order to sift out what is real opinion or just transitory prejudice' (Cable). But they also understand that all opinions, regardless of the source, are biased in some way: 'you're always mindful that they had an interest sometimes in opposing or supporting a particular policy' (Solberg); 'everyone's got an agenda' (Bennett) and 'none of this is value free, none of it. There's no objective truths, there are policy options' (Carr). Professional groups obviously argue in their own interest; the select committee process in parliament 'tends to attract people with a particular stance on an issue' (Coleman); consultation exercises tend to attract 'people with a view' or 'a strong vocation' (Borrows); expert and advisor conclusions are based on 'on particular presumptions' (Burke). It doesn't meant such views are wrong or should be dismissed-it should all be listened to-but in combination with alternative perspectives: 'any professional occupation that bring forward a request for legislation or regulation, it will, by nature, be self-serving...you have to measure that against the other interested people who will be effected' (Day).

Ministers also discussed the need to reflect on the skill of those putting forward an argument. Just because a civil servant or professional lobbyist is more effective at making a case does mean their point is superior to that made by a member of the public: 'you couldn't treat it like a court where you might give added value to the strength within advocacy' (Griffin). They need to assess how robust the information is by testing it against other views:

'Some of the assumptions upon which that advice was determined, I would have tested. I'd also test the assertions made by stakeholders. So if someone said to me the following about housing which did not accord with my own internal advice I would ask the department to test it, or I would appoint someone independent of this Parliament' ( $\mathrm{O}^{\prime}$ Connor).

'What you've got to do is assess that information against your anecdotal understanding, looking for clues that maybe the information is not as robust as it looks. So, by definition, if you've got a set of information telling you that the economy's strong and consumer confidence is high or whatever and the people you are talking to, day in day out in the area you represent, are all wringing their hands and worrying about where their next meals coming from then...ask yourself "well, why is there such a contrast?"' (Tanner).

'We have to look at the credibility of the organisations of the people that are interacting with us and, like in any situation, at least try to test the validity of what's being said. So number one "is the description of the problem accurate?"' (Grindler).

Political leadership is not only about getting a wide variety of input, but assessing its' quality, synthesising the multi-perspectives it offers, and interpreting the lessons it offers carefully.

Given this, political leaders are thus moving to a deliberative form of leadership consisting of getting out and about, consulting, sharing solution finding and judging.

\subsection{Out and About: Deliberative Political Leaders Get Out Of the Office and Interact With Those on the Ground, on the Street and Working in the Front Line to Inform Their Decisions}

There was a strong sense amongst the interviewees of the need to get out of government and out in the community-whether this was the general public or front line public sector staff-to ensure they had an effective feel for what was going on. The NZ Minister for Courts Chester Borrows described his leadership as 'I get out and about...we go out early and then we think about what we've been told before we make a decision'. Others talk of getting 'out of the Bowen triangle' [the heart of NZ government] (Joyce) and 'meeting businesses up and down the country' (Green). Gary Grindler recalled how he and the US Attorney General once flew to a centre where young men and women who had experienced a variety of problems in their lives were boarding for a period of time and they had a private conversation with every young man and women in the class receiving the programme to get their perspective on what was working or needed changing. Deliberative political ministers don't want to wait for people to come to them: 'you need to get out in the broader community and go and talk to the local shopping centre owners and community groups' (McClelland). There is also a strong physical as- 
pect to this with discussions about supermarkets, sports clubs, fairs, markets and barbecues: see Figure 4 .

\subsection{Consultative: Deliberative Political Leaders Listen to a Range of Perspectives in Participatory Dialogue before Making Decisions}

When asked directly about their leadership style a common theme was consultative, collaborative, listening or participatory. As Bill English, NZ Deputy PM said 'political leaders have got choices about how they do business.... when you chose a course that is more participative...you can build higher levels of trust through the process'. Others talked of being 'inclusive' and 'taking on board other people's opinions and views' (Gillan); being 'very open, very transparent...we were very collaborative and we listened to all points of view and really followed the recommendations and suggestions' (La Hood); 'consultative...actually asking...people who do the job' (Collins); and 'talking to groups and to interested parties' (Evans). This doesn't take away the politician's right to make decisions but as English said 'you can get there without having to assert that roleyou gain greater trust'.

\subsection{Shared-Solution Finding: Deliberative Political Leaders Work in Partnership with Those outside Government to Identify Solutions; Sharing Responsibility as Well as Power with the Public}

Building on this, ministers also discussed moving to another level and working with others to identify solutions. Thus 'delivering through government is, in essence, about partnerships' (Crean) and ministers seek to 'share policy formation' (Spelman). They focus on the way forward, 'working hard with members of the public to say what's the solution' (Woodhouse); 'getting people that participated in solving a problem' (Ev- ans); 'getting alongside each other to work out what we need to do' (Bennett) and 'work[ing] with them to achieve better outcomes' (McCully).

For example Caroline Spelman, former UK Secretary of State for the Environment, Food and Rural Affairs, noted how the concept of responsibility sharing in animal welfare has been achieved in the UK and basically we set up a board which is part industry, part stakeholder, part politicians, to look at the transition to sharing the cost of animal welfare'. Similarly former US Secretary of Transport Ray La Hood recalled how they sponsored two distracted driving summits which engaged people from all over the country: 'we got input from them about what the problem is, but also about what the solution is. We engaged the telecommunication companies, the cell phone companies, the car manufacturers, and law enforcement and legislators'. It isn't an equal partnership-as New Zealand Social Development Minister Paula Bennett said 'at the end of the day I've got levers in power that they don't have' - but it is about working together. It is about seeing that 'all people have leadership in them and all people can be leaders' (Collins) and 'losing that power though by the day' (Bennett) and being 'prepared to share power' (Spelman).

\subsection{Judging: Deliberative Political Leaders Exercise Careful Judgment by Weighing Up Public Input before Then Deciding the Best Course of Future Action}

Finally, political leaders do of course have to make decisions in government and thus making their own judgement remains part of the new leadership model. Ministers get to a 'time where you draw the line' (Foss) and 'that's as far as you can go, and then you move' (Griffin). Talking about that decision making stage, ministers discussed weighing up the merits of different inputs, arguments and factors; judging the input they have received; and balancing conflicting perspectives.

'Sitting by a booth at a farmers market or a trade fair and people can just walk up and give you their views on unsolicited, unfiltered.'

Stockwell Day, former Canadian Minister for International Trade

'I spend a lot of time doing site visits; a lot of time out of the office, a lot of time out on the ground' Tony Burke, Australian Minister for Sustainability

'You've got to get grass roots, put your sneakers on, go in.'

Paula Bennett, New Zealand Minister for Social Development

'You've actually got to go to the frontlines to see what's going on, and to see some of the issues that people have and say "why is that like that? What can we do?"...you have to get out of the office to go and do that.'

Judith Collins, New Zealand Minister of Justice

'Watching my sons play soccer on the weekend one of the most useful forums, because if it really was an issue with people they'd raise it with you. If it was just a Canberra or press issue, an insider's issue, people wouldn't raise it with you.'

Chris Evans, former Australian Minister for Immigration and Citizenship

'You meet on the marae. And you go face to face, eye to eye. And that's the only way.'

Pita Sharples, New Zealand Minister for Maori Affairs

'Go to the rugby club and wander up to the supermarket and actually people come up and tell you what they think...the type of people who won't make an appointment with an MP because they are just too busy.'

Jonathan Coleman, New Zealand Minister of Defence

Figure 4. Ministers' discussions of getting out and about physically. 
As one interview joked, whilst it would be good if there were 'a secret chemistry!' (Joyce) there isn't a clear formula for this. Instead, politicians have to use their judgement. As Chris Evans, former Australian Minister for Immigration and Citizenship explained 'you don't actually ever say "well I value this as point seven percent of the decision making process." There's no formal calculation. But it's just judgements you make after the range of inputs'.

And of course practical politics has to be brought into the final decisions, considering in Canada for example 'how would they view this at the Tim Hortons?' (Clement); or in New Zealand 'as the Prime Minister is one to say "it's not a game of perfect we're playing here, it's politics"' (Joyce). Or in the US 'the White House is a part of the policy discussion of course because they may be the ultimate decision makers' (Grindler) and in Canada 'you receive a letter from the Prime Minister telling you "I want to see you working on this, and on these matters"' (Blackburn). But overall these final decisions are better made after getting appropriate input: once decisions are made ministers are responsible for them and they can be 'most confident in making those decisions when you feel you've given an opportunity for all sorts of input to come to you as the decision maker' (Bird).

\section{The Value of Deliberative Political Leadership}

In their interviews ministers also explained why being more consultative and collaborative helps them be leaders. It creates more options, improves policy, identifies politically-doable solutions, creates support for change, saves money and helps policies work as intended. They recalled how 'I learnt things that sent me off in different directions' (Bennett) and input can 'alert you to what may have been unforeseen or unpredicted consequences that with some amendment and change can make the policy outcomes better' (Bird). Being open to input can help identify where opposition might be overcome: 'having a public debate has made the possibility of change much more possible in a whole range of areas' (Evans). It also creates legitimacy and acceptance for decisions and increases compliance once legislation is enacted or new programmes implemented: 'it gives people a stake in saying "hey, we helped solve this problem. And here's the solution." And many of these people are the ones who carry out the solution' (La Hood). Ministers need to be 'prepared to modify your thinking based on any valid contributions that they make' as 'they may well come out and defend it, because it becomes their document' (C. Emerson).

Adopting a more collaborative form of leadership also helps creates long-lasting change, thereby supporting leaders' vision and generating political capital to lead more change. Simon Crean, former Australian
Minister for Regional Australia noted that those initiatives he had taken the time to develop with public input had 'stood the test of time. They haven't been unpicked'. Paula Bennett's comments on this echoed her counterparts' concessions of not being the source of all power and knowledge: 'if the community doesn't own this thing I will come and go. So yes I've shown the leadership to get it going, I push it, I'm important. But I will be gone and they will be far more important than I am...unless they are completely brought into it, and now are owning it on the ground, it's only another fancy piece of paper'.

\section{Implications: Opening Our Eyes to More Collaborative and Constructive Political Leadership}

Changing conditions and contexts require new leadership approaches in government, with Sorensen (2006, pp. 105,112 ) arguing that 'politicians must govern society in new ways' and we need the 'formulation of a new politician role'. This article provides such a role: the Deliberative Political Leader. Deliberative political leaders consider constructive and conversational input from inside and outside government from a diverse range of sources, evaluate the relative quality of such input, and integrate the input into their deliberations on what is the best way forward before making their final decision. They get out and about, consult, and share the process of solution-finding before weighing up all the information when making their final judgement. Through 51 interviews with government ministers in the UK, US, Canada, Australia and New Zealand it has become evident that senior politicians are evolving to less authoritative, power-focused leaders who accept the limits of their own power and knowledge, proactively seek greater non-governmental input into their decision making, and reflect on such ideas before making their own decisions. This fits with many existing conceptual arguments in existing literature as to what political leaders should be like. But it provides empirical evidence that political leaders are actually like that in practice not just theory.

This new theoretical model can be used in future empirical research on other ministers, government departments, and prime ministers/presidents. It could also be applied to lower levels of government such as governors and mayors. Whilst it is unlikely that all leaders will fit into this concept on all policies all of the time, by opening our eyes to the possibility we will be more likely to identify such developments in political leadership behaviour. Future research could also use alternative methods of empirical research instead of self-reported perspectives in elite interviews, such as analysis of politician's speeches, policies and actions to further explore the extent to which this new model is being followed. It could also connect more directly with 
policy making, connecting with scholarship on the complex origins of leaders' policy making and review to what extent the input they receive now comes from more and more actors.

The broader implications of this research are also that the nature of political leadership is less certain. As the Deputy Prime Minister of New Zealand Bill English observed, leaders need to develop 'the ability to tolerate ambiguity and non-linear processes' which can be 'more challenging of leadership because it's less predictable'. It also makes governance more pluralistic, organic, intuitive and fluid and 'uses use frameworks that don't always fit with the mainstream public policy analysis'. Political power is less defined: as another interviewee put it, 'political power is very much overstated these days. I think power in our community is very diffuse' (Evans). Instead of seeking and then using formal power, political elites are more facilitators of discussion to create solutions before making their final judgement. There is a sense of powerless power: politician's authority is contested and complex and has to be constantly renegotiated. Both research and practice needs to take account of this more complex and chaotic understanding of political leadership and explore more suitable responses such as the more deliberative form of leadership suggested by this article.

\section{Acknowledgements}

This research was supported by a Faculty of Arts research development fund grant from The University of Auckland.

\section{Conflict of Interests}

The author declares no conflict of interests.

\section{References}

Aberdach, J. D., \& Rockman, B. A. (2002). Conducting and coding elite interviews. Political Science and Politics, 35(4), 673-676.

Barber, J. D. (1988). Politics by humans: Research on American leadership. Durham, NC: Duke University Press.

Bell, D., Hargrove, E. C., \& Theakston, K. (1999). Skill in context: A comparison of politicians. Presidential Studies Quarterly, 29(3), 528-548.

Boin, A., McConnell, A., \& t'Hart, P. (2010). Crisis leadership. In R. A. Couto (Ed.), Political and civic leadership: A reference handbook (pp. 229-239). Thousand Oaks, CA: Sage.

Brooker, P. (2005). Leadership in democracy: From adaptive response to entrepreneurial initiative. Basingstoke: Palgrave Macmillan.

Burkhardt, J. C., \& Glass, C. R. (2010). Public opinion and public judgment. In R. A. Couto (Ed.), Political and civic leadership: A reference handbook (pp 560570). Thousand Oaks, CA: Sage.

Burns, J. M. (1977). Wellsprings of political leadership. The American Political Science Review, 71(1), 266275.

Cheyne, C. (2004). Changing political leadership: The New Zealand mayor in contemporary local governance. Political Science, 56(2), 51-64.

Coleman, S. (2005). Blogs and the new politics of listening. The Political Quarterly, 76(2), 273-280.

Cooperrider, D. L., Whitney, D., \& Stavros, J. M. (2008). Appreciative inquiry handbook: For leaders of change. Oakland, CA: Berret-Koehler Publishers.

Edwards G., \& Wood, B. D. (1999). Who influences whom? The President, Congress, and the media, American Political Science Review, 93(2), 327-344.

Elgie, R. (1995). Political leadership in liberal democracies. New York, NY: St Martin's.

Genovese, M. A. (1994). Thomas Jefferson and the vision of democratic leadership. Journal of Leadership \& Organizational Studies, 1(3), 22-25.

Genovese, M. A. (2008). Memo to a new president: the art and science of presidential leadership. New York, NY: Oxford University Press.

Goldstein, K. (2002). Getting in the door: Sampling and completing elite interviews. Political Science and Politics, 35(4), 669-672.

Goodin, R. (2009). Innovating democracy: Democratic theory \& practice after the deliberative turn. Oxford: Oxford University Press.

Hartley, J. (2011). Learning in the whirlwind: Politicians and leadership development. Public Money \& Management, 31(5), 331-338.

Hartley, J. (2012). Political leadership. In A. Weinberg (Ed.), The psychology of politics (pp 97-120). Cambridge: Cambridge University Press.

Hartley, J., \& Benington, J. (2011). Political leadership. In A. Bryman, D. Collinson, K. Grint, B. Jackson, \& M. Uhl-Bien (Eds.), The Sage handbook of leadership (pp. 203-214). London: Sage.

Helms, L. (2005). Presidents, Prime Ministers and Chancellors: Executive leadership in Western democracies. Basingstoke: Palgrave.

Jacobs, L. R., \& Shapiro, R. Y. (2000). Polling and pandering. Society, 37(6), 11-13.

Kane, J., \& Patapan, H. (2012). The democratic leader: How democracy defines, empowers, \& limits its leaders. Oxford: Oxford University Press.

Kernell, S. (1986). Going public: New strategies of presidential leadership. Washington, DC: CQ Press.

Klijn, E., \& Koppenjan, J. F. M. (2000). Politicians and interactive decision making: Institutional spoilsports or playmakers. Public Administration, 78(2), 365387.

Komives, S. R., \& Dugan, J. P. (2010). Contemporary leadership theories. In R. A. Couto (Ed.), Political and civic leadership: A reference handbook (pp. 
111-120). Thousand Oaks, CA: Sage.

Lees-Marshment, J. (2012). Political marketing and opinion leadership: Comparative perspectives and findings. In L. Helms (Ed.), Comparative political leadership (pp. 165-185). Basingstoke: Palgrave.

Lees-Marshment, J. (2015). The ministry of public input. Basingstoke: Palgrave.

Lilleker, D. G. (2003). Interviewing the political elite: Navigating a potential minefield. Politics, 23(3), 207-214.

Lipman-Blumen, J. (2010). Connective leadership. In R. A. Couto (Ed.), Political and civic leadership: A reference handbook (pp. 771-781). Thousand Oaks, CA: Sage.

Masciulli, J., \& W. A. Knight (2009). Conceptions of global leadership for political leaders. In J. Masciulli, M. A. Molchanov, \& W. A. Knight (Eds.), The Ashgate research companion to political leadership (pp. 457-492). Surrey: Ashgate.

Nabatchi, T., \& Farrar, C. (2011). Bridging the gap between public officials and the public. A report of the Deliberative Democracy Consortium. Retrieved from http://www.deliberative-democracy.net

Neustadt, R. E. (1960). Presidential power: The politics of leadership. New York: Wiley \& Sons.

Peele, G. (2005). Leadership and politics: A case for a closer relationship? Leadership, 1(2), 187-204.

Peele, G. (2011). Leadership and politics: A case for a closer relationship? In D. S. Bell (Ed.), Political leadership (Vol. I, pp. 223-242). London: Sage.

Rhodes, R. A. W., t'Hart, P, \& Noortdegraaf, M. (2007). Observing government elites: Up close and personal. Basingstoke: Palgrave.

Richards, D. (1996). Elite interviewing: Approaches and pitfalls. Politics, 16(3), 199-204.

Riddell, P., Gruhn, Z., \& Carolan, L. (2011). The challenge of being a minister: Defining and developing ministerial effectiveness. The Institute for Government. Retrieved from http://www.instituteforgov ernment.org.uk/publications/challenge-beingminister

Sorensen, E. (2006). Metagovernance: The changing role of politicians in processes of democratic governance. The American Review of Public Administration, 36(1), 98-114.

Whitney, D. (2007). Designing organizations as if life matters: Principles of appreciative organizing. In $\mathrm{M}$. Avital, R. J. Boland, \& D. L. Cooperrider (Eds.), Designing information and organizations with a positive lens (Vol. 2, pp. 329-363). Bingley: Emerald Group.

\section{About the Author}

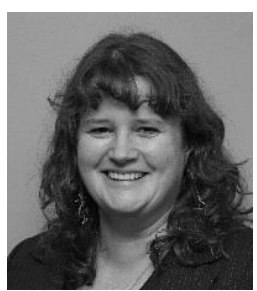

Jennifer Lees-Marshment is an Associate Professor in political science at The University of Auckland in New Zealand. Author/editor of 13 books, Jennifer is a world expert in political marketing with additional research interests in public input, leadership, and governance. Her most recent work The Ministry of Public Input (Palgrave 2015) won the IAP2 Australasia Research Award. Jennifer was academic advisor to TVNZ's Vote Compass in the 2014 New Zealand election and Chair of the Magna Carta 800 committee for NZ in 2015. See www.lees-marshment.org for further details. 